\title{
Archival Deposition
}

On the decision of the Canadian Political Science Association and la Société canadienne de Science politique, arrangements have been concluded to deposit files of manuscripts submitted to the JOURNAL/REVUE and correspondence relating to those manuscripts (including assessments received) in archive collections. These files will be accessible for research purposes some years in the future. In the case of existing files and manuscripts received to the end of 1978 , the files will remain closed for twenty years from the date on which those manuscripts were submitted. In the case of future manuscripts, those received in 1979 and after, such files will be closed for a ten-year period.

The English-language manuscripts still extant will be deposited in the Public Archives of Canada in Ottawa. The French-language manuscripts will be deposited in the Bibliothèque Nationale in Montreal.

The business correspondence of the JOURNAL/REVUE will be held for three years, but after transfer to the archive collections will be accessible without a time restriction.

\section{Dépôt aux archives}

A la suite de la décision conjointe de l'Association canadienne de science politique et de la Société canadienne de science politique, des dispositions ont été prises afin de déposer aux archives les manuscrits soumis à la REVUE et la correspondance afférente ( $\mathrm{y}$ compris les évaluations). Ces documents seront disponibles pour fins de recherches dans un certain nombre d'années selon les restrictions d'accessibilité suivantes. Dans le cas des dossiers et des manuscrits existants ainsi que ceux reçus jusqu'à la fin de 1978, il y aura un embargo de 20 ans à partir du moment où ils ont été soumis. Dans le cas des manuscrits à venir, ceux reçus en 1979 et après, il y aura un embargo de 10 ans.

Les manuscrits de langue anglaise qui existent encore seront déposés aux Archives publiques du Canada, à Ottawa. Les manuscrits de langue française seront déposés à la Bibliothèque nationale du Québec, à Montréal.

La correspondance relative aux affaires courantes sera conservée pendant trois ans mais après le dépôt aux archives elle sera accessible sans restriction de temps. 